\title{
INFLUENCE OF BIOLOGICAL SEWAGE TREATMENT ON THE RECEIVING WATERS OF HOTELS AND MANAGEMENT OF ECONOMIC BENEFIT
}

\author{
LIJIAN ZHANG \\ Qingdao Vocational and Technical College of Hotel Management, Qingdao, China.
}

\begin{abstract}
The development of economy and the improvement of living standard promote the generation of more and more hotels. The problem of hotel sewage treatment has also been concerned. Finding a sewage treatment method which considers benefits of both environment and economy is an urgent problem. Taking sewage treatment in a hotel in Qingdao, China, as the object, biological aerated filter was used in hotel waste water treatment. The results demonstrated that chemical oxygen demand (COD), Biochemical oxygen demand $\left(\mathrm{BOD}_{5}\right)$ and ammonia nitrogen all achieved good decontamination effects, the effluent quality was significantly improved, and the environmental and economic benefits were also acceptable. Thus it is feasible to apply biological aerated filter in hotel sewage treatment as it is positive to hotel management and can bring good environmental and economic benefits.
\end{abstract}

Keywords: biological aerated filter, environment, economy, management, sewage treatment.

\section{INTRODUCTION}

Sewage treatment cannot be ignored in the modern society. With the development of related technologies, the level of sewage treatment in China has been gradually improved, and urban sewage has been well disposed. Compared with urban sewage treatment, hotel sewage treatment has some particularities. Hotels, especially those in scenic spots, are mostly located in the fringe of the city where is lack of a complete municipal sewer network. It is neither economical nor scientific to integrate them into the urban pipeline network for centralized sewage treatment. The construction of large-scale drainage pipe network and sewage treatment plant requires very high cost and long construction time, and the difficulty and cost of maintenance are also high, which brings great pressure to hotels. In off-season, these sewage treatment resources will be idle, resulting in a waste of capital. How to treat hotel sewage efficiently and cheaply to ensure the environmental and economic benefits of hotels is an increasingly important part of hotel management.

Calheiros et al. [1] established a horizontal underground flow constructed wetland system for the treatment of hotel sewage. It was found that the system not only had a strong sewage treatment function, but also had up to $90 \%$ removal efficiency of biochemical oxygen demand (BOD) and chemical oxygen demand (COD) and had aesthetic value. Yue et al. [2] adopted a decentralized wastewater treatment technique, which combined hydrolytic acidification with secondary biological contact oxidation and applied it to the sewage treatment of a hotel in Xi' an, Shaanxi, China. It was found that the technique showed high removal rates of COD and BOD5 in the raw water. Shang [3] improved the sewage treatment system in hotels through cancelling biomechanical system, performing secondary oil removing and adding deodorization system to enhance the proficiency of sewage treatment in hotels. Warlina et al. [4] treated hotel sewage with electrocoagulation and adsorption method and evaluated its performance in processing hotel sewage. Otunyo et al. [5] studied the activated sludge sewage treatment system of a hotel in Harcourt Port, Rivers State, Nigeria and found that the effluent after treatment using the system satisfied the federal environmental standards. 
Biological aerated filter has a good performance in the treatment of small-scale domestic sewage. In this study, biological aerated filter was applied to the treatment of hotel sewage. Taking a hotel in Qingdao as an experimental pilot study, the analysis of raw water and effluent of the hotel suggested that biological aerated filter had a good performance in processing hotel sewage and could effectively improve the environmental and economic benefits of the hotel. This study provides a new idea for the treatment of hotel sewage and makes some contributions to the further study of hotel sewage.

\section{SELECTION OF HOTEL SEWAGE TREATMENT TECHNIQUE}

The hotel is located in the edge of Qingdao, Shandong, China, and it is difficult to be integrated into the urban sewage treatment system. The hotel covers a small area and has the functions of accommodation and catering. There are 120 rooms in the hotel. The sewage includes domestic sewage such as catering and toilet. The total amount of sewage is about $240 \mathrm{~m} 3 /$ day. According to conditions such as the area of the hotel and requirement for effluent quality, biological aerated filter, sequencing batch activated sludge process and circulating activated sludge process were selected for comparison. The results are shown in Table 1.

It was found from the comparison in Table 1 that biological aerated filter had high effluent quality, low equipment and operation cost, simple operation and easy maintenance management. Therefore biological aerated filter was selected as the sewage treatment process for the hotel.

\section{BIOLOGICAL AERATED FILTER FOR SEWAGE TREATMENT}

Hotel sewage treatment has higher requirements for effluent. Physical method obviously does not meet the requirements, chemical method is also not suitable as it needs to a large number of chemicals and has high cost. Therefore, it is more appropriate to use biological method in hotel sewage treatment. Biological methods include biofilm process, anaerobic biological treatment process and activated sludge process [7]. Biological aerated filter can satisfy the requirement of hotel management as it has advantages of high efficiency, small occupation and convenient management. Therefore, the application of biological aerated filter in hotel sewage treatment was studied in this paper.

Table 1: Comparison of sewage treatment processes [6].

\begin{tabular}{|c|c|c|c|}
\hline Process & $\begin{array}{l}\text { Biological } \\
\text { aerated filter }\end{array}$ & $\begin{array}{l}\text { Sequencing batch } \\
\text { activated sludge } \\
\text { process }\end{array}$ & $\begin{array}{l}\text { Circulating activated } \\
\text { sludge process }\end{array}$ \\
\hline $\begin{array}{l}\text { Effluent } \\
\text { quality }\end{array}$ & Good & Good & General \\
\hline $\begin{array}{l}\text { Cost of } \\
\text { equipment }\end{array}$ & Low & Moderate & Moderate \\
\hline $\begin{array}{l}\text { Cost of } \\
\text { operation }\end{array}$ & Low & Slightly high & Slightly high \\
\hline Operation & Simple & Relatively simple & Relatively simple \\
\hline $\begin{array}{l}\text { Maintenance } \\
\text { management }\end{array}$ & Easy & Easy & Easy \\
\hline
\end{tabular}




\subsection{Principles}

Biological aeration filter [8] is a kind of biofilm process. It combines biological oxidation with adsorption filtration in the same reactor. Sewage will be rapidly purified when flowing through the filter materials with small grain size such as ceramsite and coke with biofilms on the surface because of the biological metabolism effect, and moreover the suspended solids in sewage will be intercepted because of bioflocculation, the physical absorption of filler and the graded predation of food chain in the direction of water flow. After a period of time, the suspended solids intercepted are released via back wash.

Compared to the traditional biofilter, biological aerated filter has functions of biological metabolism, bioflocculation and physical absorption and moreover has advantages of high processing efficiency, reasonable microbial community structure, high tolerance to water impact, high oxygen transfer efficiency of granular filler layer, low aeration quantity and low operation energy consumption. Compared to other sewage treatment process, it has advantages of smaller floor area, simpler operation, lower construction cost, less peculiar smell and no occurrence of sludge expansion.

\subsection{Pilot plant}

3.2.1 Technical process of the experimental facility

The experimental facility of biological aerated filter is shown in Fig. 1.

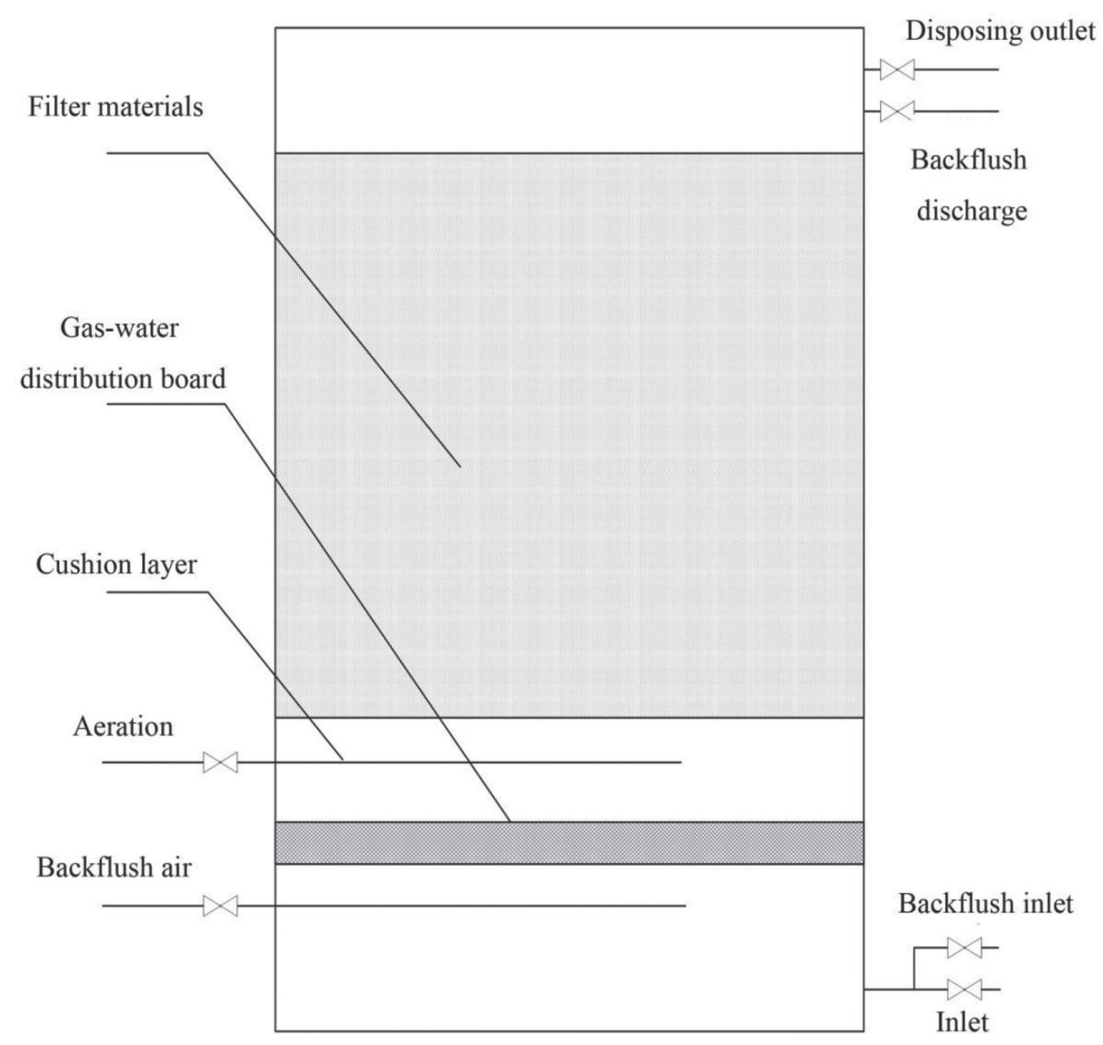

Figure 1: The experimental facility of biological aerated filter process. 
The biological aerated filter was made of polymethyl methacrylate and was $9.5 \mathrm{~m}$ wide and $2 \mathrm{~m}$ high. The height of the filter material was $1.2 \mathrm{~m} .2 .5 \mathrm{~cm}$ aeration head was used. A 100-L bucket was used as water tank. The sampling port was $10 \mathrm{~cm}$ above the bottom. Up-flow biological aerated filter was used in the test. Sewage and air entered from the bottom and flew out from the top. After sewage entered the filter, air was pumped in using an air compressor. When sewage passed through the filtering materials, organic substances were decomposed. Biological aerated filter was backwashed after a period of time because of the interception of suspended matters and detachment of aged biofilms. Air-water combined backflush was performed by closing the inlet valve and opening the backflush valve. After backflush, the inlet valve was reopened, and the sewage treatment of next cycle started.

\subsubsection{Test conditions}

1. Filtering materials

Filtering materials is an important part of biological aerated filter and can has a significant influence on the effectiveness, structure and cost of process. Therefore the selection of filtering materials is important for biological aerated filter process.

Multiple factors should be considered in the selection of filtering materials. Regular sphere, large specific surface area, favorable mechanical performance and porous and rough surface were preferred [9]. Moreover the density should be moderate, and favorable chemical stability and resistance to corrosion were needed to prevent damages. The cost of filtering materials took a large proportion. The price should also be taken into account.

Considering the multiple factors, porous ceramsite biological filtering material was selected. Its main performance is shown in Table 2. Porous ceramsite has large specific surface area, high porosity, favorable biofilm culturing performance, regular shape, small resistance and high chemical and physical stability, suggesting a high cost performance [10].

2. Water quality and analysis method

The hotel sewage was mainly composed of fecal sewage and restaurant sewage, which had a high concentration of nitrogen phosphorus and contained a large number of bacteria and oil substances. The water quality of the sewage is shown in Table 3.

The predicted quality of water after treatment is shown in Table 4.

Table 2: Main performance parameters of porous ceramic.

\begin{tabular}{lc}
\hline Performance & Parameters \\
\hline Specific surface area $\left(\mathrm{m}^{2} \cdot \mathrm{g}^{-1}\right)$ & $\geq 4 * 10^{4}$ \\
Porosity $(\%)$ & $>30$ \\
Density $\left(\mathrm{g} \cdot \mathrm{m}^{-3}\right)$ & $\leq 2.3$ \\
Solubility in hydrochloric acid $(\%)$ & $\leq 0.5$ \\
\hline
\end{tabular}

Table 3: Quality of the sewage influent.

\begin{tabular}{lcccc}
\hline & COD & Ammonia nitrogen & SS & BOD $_{\mathbf{5}}$ \\
\hline Raw water $(\mathrm{mg} / \mathrm{l})$ & 350 & 30 & 280 & 200 \\
\hline
\end{tabular}


Table 4: The predicted quality of effluent.

\begin{tabular}{lcccc}
\hline & COD & Ammonia nitrogen & SS & BOD $_{\mathbf{5}}$ \\
\hline Effluent $(\mathrm{mg} / \mathrm{l})$ & 50 & 12 & 70 & 20 \\
\hline
\end{tabular}

Table 5: The main supervision indicators and testing methods.

\begin{tabular}{ll}
\hline Indicators & Methods \\
\hline $\mathrm{COD}$ & Potassium dichromate method \\
Ammonia nitrogen & Nessler's reagent spectrophotometry \\
$\mathrm{SS}$ & Gravimetric method \\
$\mathrm{BOD}_{5}$ & Standard dilution method \\
\hline
\end{tabular}

Removal rate of pollutant concentration $=$ [influent concentration $(\mathrm{mg} / \mathrm{L})-$ effluent concentration $(\mathrm{mg} / \mathrm{L})] /$ influent concentration $(\mathrm{mg} / \mathrm{L}) * 100 \%$.

The detection method of water quality followed Supervision and Analysis Methods for Water and Sewage (the 3rd edition) [11]. The main instruments used included 722 spectrophotometer, balance and PH meter. The main test indicators and methods are shown in Table 5

\subsection{Experimental process}

Inoculation was used in biofilm formation of biological aerated filter and the inoculated sludge came from the secondary sedimentation tank of oxidation ditch of a sewage treatment plant. Ceramisite filter material was immersed with activated sludge and added with nutrient substances in a ratio of $\mathrm{C}: \mathrm{N}: \mathrm{P}=100: 5: 1$. Then the ceramsite was put into a reactor for aeration, and the aeration rate was $5 \mathrm{~L} / \mathrm{h}$. The air water ratio was kept 7:1 10:1. Manual sampling was performed at the same time everyday. Five samples were collected every time, and one sample was selected randomly for detection.

\section{TEST RESULTS}

The sewage treatment result after 30 days is shown in Table 6.

It was found from Table 6 that the sewage treatment result has reached the predetermined standard after 30 days, indicating treating hotel sewage with biological aerated filter was

Table 6: Sewage treatment effect.

\begin{tabular}{lcc}
\hline Indicator & Effluent $(\mathbf{m g} / \mathbf{l})$ & Removal rate $(\%)$ \\
\hline COD & 39.21 & 88 \\
Ammonia nitrogen & 11.37 & 62 \\
$\mathrm{SS}$ & 42.12 & 85 \\
$\mathrm{BOD}_{5}$ & 12.57 & 94 \\
\hline
\end{tabular}


feasible. The biological aerated filter system continued to operate, and the data of raw water and effluent during three months was collected.

1. Removal of COD

COD can reflect the pollution degree of water. Larger value of COD indicates more serious pollution. Table 7 shows that the COD concentration of the raw water showed an increasing tendency in the experimental period, which might be correlated to the increased customers in the transition period from the off season to the peak season, and the COD concentration of effluent increased with the increase of COD concentration in raw water. The removal rate of COD was always above $80 \%$ during the three months and the average standard deviation was 0.014 . From the perspective of long-term effect, the bological aerated filter had a good removal effect on COD. These findings indicated that biological aerated filter could effectively eliminate organic substances in sewage and shoulder large hydraulic loading.

2. Removal of ammonia nitrogen

Ammonia nitrogen is one of the most important substances that need to be removed in sewage treatment. The design of biological aerated filter is beneficial to the growth of nitrifying bacteria and can realize simultaneous nitrification and denitrification, which has a very obvious removal effect on ammonia nitrogen. Table 8 shows that the concentration of ammonia nitrogen in effluent was lower than $12 \mathrm{mg} / \mathrm{l}$ and the removal rate was higher than $60 \%$, which showed a long-term, stable removal efficiency. It was obvious that the removal efficiency of ammonia nitrogen using biological aeration filter was effective.

3. Removal of SS

The physical adsorption, filtration interception and biological oxidation of filter material in biological aerated filter achieved high efficient removal of SS. The experimental results in Table 9 demonstrated that the removal rate of SS in effluent was higher than $80 \%$, indicating effective removal. After 90 days, the removal rate of SS in the effluent reached $87 \%$, which indicated the long-term effectiveness of the sewage treatment process.

Table 7: Removal of COD.

\begin{tabular}{lccccccccc}
\hline Time/day & $\mathbf{1 0}$ & $\mathbf{2 0}$ & $\mathbf{3 0}$ & $\mathbf{4 0}$ & $\mathbf{5 0}$ & $\mathbf{6 0}$ & $\mathbf{7 0}$ & $\mathbf{8 0}$ & $\mathbf{9 0}$ \\
\hline $\begin{array}{l}\text { COD of raw water } \\
(\mathrm{mg} / \mathrm{l})\end{array}$ & 220 & 240 & 350 & 350 & 370 & 380 & 360 & 350 & 340 \\
$\begin{array}{l}\text { COD of effluent } \\
(\mathrm{mg} / \mathrm{l})\end{array}$ & 32.36 & 36.67 & 39.21 & 44.65 & 48.48 & 49.69 & 44.94 & 41.23 & 40.32 \\
Removal rate $(\%)$ & $85 \%$ & $85 \%$ & $89 \%$ & $87 \%$ & $87 \%$ & $87 \%$ & $88 \%$ & $88 \%$ & $88 \%$ \\
\hline
\end{tabular}

Table 8: Removal of ammonia nitrogen.

\begin{tabular}{llllllllll}
\hline Time/day & $\mathbf{1 0}$ & $\mathbf{2 0}$ & $\mathbf{3 0}$ & $\mathbf{4 0}$ & $\mathbf{5 0}$ & $\mathbf{6 0}$ & $\mathbf{7 0}$ & $\mathbf{8 0}$ & $\mathbf{9 0}$ \\
\hline $\begin{array}{l}\text { Ammonia nitrogen } \\
\text { of raw water (mg/l) }\end{array}$ & 27 & 26.5 & 30 & 30 & 32 & 34 & 34 & 35 & 34 \\
$\begin{array}{l}\text { Ammonia nitrogen } \\
\text { of effluent (mg/l) }\end{array}$ & 8.62 & 8.78 & 11.37 & 9.27 & 9.34 & 10.16 & 9.89 & 9.91 & 9.62 \\
Removal rate (\%) & $68 \%$ & $67 \%$ & $62 \%$ & $69 \%$ & $71 \%$ & $70 \%$ & $71 \%$ & $72 \%$ & $72 \%$ \\
\hline
\end{tabular}


4. Removal of $\mathrm{BOD}_{5}$

$\mathrm{BOD}_{5}$ refers to the amount of oxygen consumed by decomposition of organic matters. Larger value of $\mathrm{BOD}_{5}$ indicated more organic substances and more serious pollution. As shown in Table 10, the concentration of $\mathrm{BOD}_{5}$ in the effluent was lower than $20 \mathrm{mg} / \mathrm{l}$, the removal rate was higher than $90 \%$, and in the long run, the removal rate kept stable at $94 \%$, indicating that the biological aeration filter also had a high efficiency in removing $\mathrm{BOD}_{5}$.

It was found that biological aerated filter had a good performance in processing hotel sewage after three months of operation. Then the operation cost of this sewage treatment method was analyzed, and the total cost of equipment operation in one year was calculated, as shown in Table 11.

It was found from Table 11 that biological aerated filter could treat $89400 \mathrm{~m} 3 \mathrm{sew}-$ age and the total cost was 9608 USD. Overall, biological aerated filter is a high-efficient and low-cost hotel sewage treatment method.

Table 9: Removal of SS.

\begin{tabular}{lccccccccc}
\hline Time/day & $\mathbf{1 0}$ & $\mathbf{2 0}$ & $\mathbf{3 0}$ & $\mathbf{4 0}$ & $\mathbf{5 0}$ & $\mathbf{6 0}$ & $\mathbf{7 0}$ & $\mathbf{8 0}$ & $\mathbf{9 0}$ \\
\hline $\begin{array}{l}\text { SS of raw } \\
\text { water (mg/l) }\end{array}$ & 220 & 250 & 280 & 290 & 300 & 320 & 330 & 310 & 320 \\
$\begin{array}{l}\text { SS of efflu- } \\
\text { ent (mg/l) }\end{array}$ & 36.45 & 38.64 & 42.12 & 42.69 & 43.11 & 43.69 & 44.12 & 44.32 & 41.79 \\
$\begin{array}{l}\text { Removal } \\
\text { rate }(\%)\end{array}$ & $83 \%$ & $85 \%$ & $85 \%$ & $85 \%$ & $86 \%$ & $86 \%$ & $87 \%$ & $86 \%$ & $87 \%$ \\
\hline
\end{tabular}

Table 10: Removal of $\mathrm{BOD}_{5}$.

\begin{tabular}{lccccccccc}
\hline Time/day & $\mathbf{1 0}$ & $\mathbf{2 0}$ & $\mathbf{3 0}$ & $\mathbf{4 0}$ & $\mathbf{5 0}$ & $\mathbf{6 0}$ & $\mathbf{7 0}$ & $\mathbf{8 0}$ & $\mathbf{9 0}$ \\
\hline $\begin{array}{l}\mathrm{BOD}_{5} \text { of raw water } \\
(\mathrm{mg} / \mathrm{l})\end{array}$ & 160 & 180 & 200 & 210 & 225 & 230 & 244 & 236 & 215 \\
$\begin{array}{l}\mathrm{BOD}_{5} \text { of effluent } \\
(\mathrm{mg} / \mathrm{l})\end{array}$ & 10.68 & 11.36 & 12.57 & 12.94 & 13.01 & 13.68 & 14.56 & 14.31 & 13.68 \\
Removal rate $(\%)$ & $93 \%$ & $94 \%$ & $94 \%$ & $94 \%$ & $94 \%$ & $94 \%$ & $94 \%$ & $94 \%$ & $94 \%$ \\
\hline
\end{tabular}

Table 11: Analysis of equipment operation cost.

\begin{tabular}{lc}
\hline Item & Value \\
\hline Annual treatment capacity of sewage (ten thousand $\mathrm{m}^{3}$ ) & 8.94 \\
Annual energy consumption (ten thousand kwh) & 6.62 \\
Salary of management and maintenance staffs (USD) & 536 \\
Management and maintenance cost (USD) & 3992 \\
Energy charge (USD) & 5080 \\
Total cost (USD) & 9608 \\
\hline
\end{tabular}




\section{DISCUSSION}

\subsection{Analysis of environmental influence}

One of the goals of tourism is to protect the environment and resources. As a part of tourism, hotels also have an obligation to achieve it. Therefore, maintaining environmental sustainability has become an important task for hotel managers [12]. As a part of hotel environment, sewage disposal is the top priority of hotel management. The problem of hotel sewage has been effectively solved through the construction of sewage treatment system. Biological aerated filter effectively removed COD, SS, ammonia nitrogen and $\mathrm{BOD}_{5}$ in the sewage. During the three months of operation, the removal rate of COD, SS, ammonia nitrogen and $\mathrm{BOD}_{5}$ was higher than $80 \%, 60 \%, 80 \%$ and $90 \%$, respectively. The content of pollutants in the sewage satisfied the requirement, reducing the pollution of the effluent to earth surface. The influence of treated sewage on hotel greening, vegetation and groundwater was greatly reduced, which could improve the quality of surrounding environment.

The area of biological aerated filter is also smaller than that of other processes and has no great impact on the overall appearance of hotels. In addition, the technology will not produce much peculiar smell, and will not bring negative feelings to hotel customers.

Selecting an environmentally friendly hotel sewage treatment process can only increase the job satisfaction of employees, but also may promote employees' environmental protection behaviors outside hotels and set up a better image for hotels [13].

In a comprehensive view, biological aerated filter is effective in sewage treatment, which is beneficial to the sustainable development of the surrounding environment of hotels. The improvement of domestic sewage water quality not only improves the environmental quality and brings good feelings to customers and the surrounding residents, but also sets up a more positive image for hotels.

\subsection{Analysis of economic benefits}

In order to obtain a nice profit in fierce competition, cost management is an important part of hotel management. Proper cost control can improve the core competitiveness of hotels [14]. Biological aerated filter is a choice considering effectiveness and economical efficiency. In the process of operation, the intercepted pollutants and exfoliated biofilms were removed by backwashing, and the secondary sedimentation tank was not used. The application of economical porous ceramsite further reduced the construction cost. Moreover management fees, maintenance fees, staff salaries and so on were all within reasonable limits, which will not cause excessive consumption. The annual sewage treatment capacity of biological aerated filter was $89,400 \mathrm{~m}^{3}$ and the total cost was 9608 USD; hence it is an economical and effective sewage treatment method.

Compared to centralized sewage treatment, biological aerated filter can work without pipeline network construction and moreover will not cause mass consumption of resources. The filtering materials used in biological aerated filter provide a better growth environment for microorganism, which is beneficial to biofilm formation. The large microbial biomass in unit volume increases volumetric loading, which leads to the decrease of tank volume and floor area. Therefore the construction cost is reduced. 
In the aspect of hotel management, the application of biological aerated filter can not only improve the quality of surrounding environment and attract more potential clients, but also obtain the maximum output with the minimum input, suggesting high economic benefits.

\section{CONCLUSION}

Based on the analysis of the status of hotel sewage treatment, the existing hotel sewage treatment technologies were compared. On the premise of the effectiveness and the economical efficiency, the sewage treatment technologies suitable for hotels were summarized. Biological aerated filter was applied in the sewage treatment of a hotel. After analyzing the effectiveness, environmental benefits and economic benefits, it was found that biological aeration filter had better treatment effect compared with other processes, and the removal rates of $\mathrm{COD}$, ammonia nitrogen, $\mathrm{SS}$ and $\mathrm{BOD}_{5}$ were high, which was beneficial to the protection of the surrounding environment of the hotel. Moreover the cost of infrastructure was low because of its small occupation area, suggesting good economic benefits. In conclusion it has a great development prospect in the treatment of hotel sewage and has great values in hotel management. However, there are still some shortcomings in the biological aerated filter in China, such as short operation cycle, frequent backwashing and insufficient study on its performance in removing nitrogen and phosphorus. To exert its greater efficacy in sewage treatment, further tests and researches are needed.

\section{REFERENCES}

[1] Calheiros, C.S., Bessa, V.S., Mesquita, R.B., Brix, H., Rangel, A.O. \& Castro, P.M., Constructed wetland with a polyculture of ornamental plants for wastewater treatment at a rural tourism facility. Ecological Engineering, 79, pp. 1-7, 2015.

[2] Xie, Y., Li, X.M. \& Zhang, Z., Application of distributed processing technology to hotel sewage treatment engineering. Industrial Water Treatment, 34(12), pp. 84-86, 2014.

[3] Shang, J., Technical renovation project of wastewater treatment station of a hotel. Water Purification Technology, 35(3), pp. 107-110, 2016.

[4] Warlina, L. \& Simanjuntak, W., Treatment of hotel wastewater with a combination of electrocoagulation and adsorption using carbosil. Journal Sylva Lestari, 1(1), pp. 85-92, 2013.

[5] Otunyo, A.W., Edward, K. \& Ogina, O.D., Evaluation of the performance of the domestic wastewater treatment facility of a hotel in port harcourt, rivers state nigeria. Nigerian Journal of Technology, 35(2), p. 441, 2016.

[6] Zhou, X., Wang, Q. \& Jiang, G., Enhancing methane production from waste activated sludge using a novel indigenous iron activated peroxidation pre-treatment process. Bioresource Technology, 182, pp. 267-271, 2015.

[7] Tabata, S.I., Suzuki, T., Hamamoto, Y., Hayakawa, N. \& Watanabe, K., Activated Sludge Method: US, US 4655925 A, 1987.

[8] Froud, D.P., Biological Aerated Filter: WO, WO 1995006010 A1. 1995.

[9] Bao, T., Chen, T., Tan, J., Wille, M.L., Zhu, D., Chen, D. \& Xi, Y.F., Synthesis and performance of iron oxide-based porous ceramsite in a biological aerated filter for the simultaneous removal of nitrogen and phosphorus from domestic wastewater. Separation \& Purification Technology, 167, pp. 154-162, 2016.

[10] Xie, J.J., Development and application of Palygorskite porous ceramsite in a biological aerated filter (BAF). Desalination \& Water Treatment, 57(4), pp. 1790-1803, 2016. 
[11] Fusheng, W, ed., Water and Waste Water Monitoring and Analysis Method, 3rd edn., China Environmental Science Press, 1989.

[12] Pramono, J., Susrusa, I.K.B. \& Wiranatha, A.S., Environmental management at star rated hotel in Bali. E-Journal of Tourism, 1(1), pp. 57-68, 2014.

[13] Sourvinou, A. \& Filimonau, V., Planning for an environmental management programme in a luxury hotel and its perceived impact on staff: an exploratory case study. Journal of Sustainable Tourism, 1, pp. 1-19, 2017.

[14] Wei, C., Analysis on cost management of modern hotel. Journal of Hebei Software Institute, 18(1), pp. 18-20, 2016. 